\title{
ANALYSIS OF ENERGY CONSUMPTION \\ BY ELECTRIC AGRICULTURAL TRACTOR MODEL UNDER OPERATING CONDITIONS
}

\author{
Krzysztof Plizga* \\ Faculty of Production Engineering, University of life Sciences in Lublin, Poland, \\ e-mail: krzysztof.plizga@up.lublin.pl, ORCID 0000-0003-0977-6625 \\ * Corresponding author: e-mail: krzysztof.plizga@up.lublin.pl

\begin{tabular}{|c|c|}
\hline ARTICLE INFO & ABSTRACT \\
\hline $\begin{array}{l}\text { Article history: } \\
\text { Received: July } 2020 \\
\text { Received in the revised form: } \\
\text { January } 2021 \\
\text { Accepted: January } 2021 \\
\end{array}$ & \multirow{2}{*}{$\begin{array}{l}\text { The aim of the paper is analysis of consumption of electric energy } \\
\text { which is necessary to drive a farm tractor with an electric motor as } \\
\text { a drive unit under the conditions of a drive with varied loading of the } \\
\text { power transmission system. The object of the research was a tractor } \\
\text { model where a combustion engine was replaced with a dc electric mo- } \\
\text { tor. During the tests, a decrease of voltage and current strength collected } \\
\text { from supplying batteries as a function of tractor drive time and in rela- } \\
\text { tion to the mass of a tractor with a trailer, temperature of the surround- } \\
\text { ing and resistance to motion were reported, which enabled determina- } \\
\text { tion of the collected power and energy. For the used set of batteries } \\
\text { also the maximum range of the tractor drive on the paved road was de- } \\
\text { termined. }\end{array}$} \\
\hline $\begin{array}{l}\text { Key words: } \\
\text { farm tractor, } \\
\text { electric engine, } \\
\text { drive system, } \\
\text { energy consumption }\end{array}$ & \\
\hline
\end{tabular}

\section{Introduction}

With the growing environmental pollution, it becomes necessary to protect it by means of effective management of natural resources, minimization of water consumption, natural fuels (petroleum derivatives), recycling (Andersen, 2013; Bakun, 2015; Chłopek, 2013; Engstle et al., 2012; Haidar et al., 2011; Hüpkes et al., 2011; Schneider et al., 2011). Vehicles, considered up to this day as the main road transport mean, are the biggest source of natural environmental pollution. To reduce their nuisance, more vehicles with a hybrid or electric drive are introduced to public use (Daberkow et al., 2013; Eckl et al., 2013; Marcus et al., 2009; Król and Rossa, 2017; Michałowski and Ocioszyński, 1989; Moons and De Pelsmacker, 2014).

Among many advantages of vehicles with a mixed drive (combustion and electric) or only with an electric one, it should be mentioned that energy collection in batteries, though it is time consuming and causes losses, may bring tangible benefits not only for the natural environment in the form of reduction of toxic elements of exhaust gases emission to atmosphere and also limitation of the amount of the consumed crude oil (traditional fuels produced therefrom) and substitute fuels (synthetic and biofuels). Electric cars may also improve load factors of electric grids reducing thus an average cost of electric energy production, since 
charging of batteries may be carried out outside the peak hours (Eckl et al., 2013). Despite this, a small range of electric cars in comparison to cars equipped with a combustion engine is still a problem that inhibits popularization of these cars (Chłopek, 2013). To eliminate this aspect, systems which may enable conversion (recovery) of electric energy with high efficiency are constructed around the world nowadays (Schneider et al., 2011).

One of the groups of vehicles which are increasingly used are farm vehicles due to their universal character, high power, and ability to work even in difficult conditions. However, because of the increasing number of tractors and their big consumption, also these vehicles have a great participation in pollution of the natural environment. Farm tractors participate also in production of food and considerably influence its quality.

\section{Objective}

The power transmission system of a farm tractor is adjusted to develop varied drive speed necessary to perform agrotechnical treatments. Simultaneously, farm tractors move in a varied terrain very often with considerable resistance to motion.

Therefore, the objective of the paper is analysis of energy consumption through an electric model of a power transmission system of a farm tractor during performance of transport works at variable loads, resistance to motion and varied temperature of the surrounding.

\section{Materials and Methods}

A farm tractor model with a brushless electric engine type BM1424ZXF with 2.2. $\mathrm{kW}$ and rated voltage $60 \mathrm{~V}$ was used for the energy consumption test of the power transmission system. The engine was supplied from the electric batteries set with $60 \mathrm{~V}(5 \times 12 \mathrm{~V})$ through PWM voltage regulator. The used gel batteries V-Pro with $12 \mathrm{~V}$ rated voltage, $120 \mathrm{Ah}$ volume made in AGM VRLA technology, that are usually used for emergency power supply of industrial automatic systems, were used in the tests. Each of the batteries was $35 \mathrm{~kg}$ (the total mass of the batteries set was $175 \mathrm{~kg}$ ). The used batteries had a deep discharge option (maximum up to $50 \%$ ), but due to the endurance at such a deep discharge, one measurement of the maximum distance which a tractor model may make to achieve the average voltage of $45 \mathrm{~V}$ of the batteries set was performed (making the voltage decrease average to $9 \mathrm{~V}$ each) for the established conditions of research. When the set measurement length of $100 \mathrm{~m}$ was being made, the voltage decrease of the set was small. During the studies, a trailer where batteries were located, was mounted to the tractor.

The tractor mass without a trailer and load was $91.5 \mathrm{~kg}$ and the trailer mass with batteries was $225 \mathrm{~kg}$. An 80-kilo weight was used as an additional load.

Consumption of energy accumulated in batteries was investigated through a measurement of the $\mathrm{U}$ voltage of the set and single batteries, current $I$ collected by the engine from the supplying set, $t$ time during operation of the tractor model at the set motion parameters and based on the obtained calculation results of power $P$ and consumed energy $E$. During the studies, the vehicle was moving under the conditions of the reduced resistance (motion on dry and relatively smooth concrete) and at the increased motion resistance (on the grass) both with a trailer and batteries (the total mass of the model, trailer and set of batteries was $316.5 \mathrm{~kg}$ ) and a trailer, batteries, and additional load (the total mass $396.5 \mathrm{~kg}$ ). 
For measurement of electric values, a digital multimeter Voltcraft VC870 with precision of indication of $0.0001 \mathrm{~V}$ within the range of the performed measurements and a clamp ammeter Voltcraft VC531 with precision of indications of $0.1 \mathrm{~A}$ with a measurement function of the maximum and minimum value, were used. Time measurement was performed with a timer. Before the drive, voltage of the batteries set without the load and after driving of the set route was measured. The performed electric measurements were based on the actual values of the registered parameters.

For the tested length of $100 \mathrm{~m}$, the tests were performed in ten iterations to eliminate errors of measurement for the subsequently used loads and conditions of operation. To eliminate the effect of batteries discharge on the results of particular measurements, they were charged between the subsequent tests. Whereas the tests of the maximum range of the drive on the applied set of batteries were carried out only one time for the set conditions of the tests (temperature of the surrounding and the weight of the set tractor-trailer).

The tests were performed for three selected temperatures of the surrounding: $20^{\circ} \mathrm{C}, 10^{\circ} \mathrm{C}$ and $0^{\circ} \mathrm{C}$ during the tractor drive on the length of $100 \mathrm{~m}$ both for the surface of a high adhesiveness factor (where the friction factor $\mu=1-$ dry concrete) and on the grass $(\mu=0.8$ ). Since the set temperatures may be achieved, the tests were performed in various seasons. The temperature of the surrounding was registered with the use of a digital thermometer before the onset of tests. The test set was stored in the temperature of the surrounding to obtain real conditions of the tractor operation.

\section{Results and Discussion}

Results of the voltage measurement of the batteries set, voltage reduction of the set after the performed tests, the current strength, driving time on the measurement length of $100 \mathrm{~m}$ by the model of the tractor driven with the direct current motor in relation to the temperature of the surrounding and loading during the drive on a dry and paved surface (dry concrete $\mu=1$ ) and the power and energy collected from the supplying set were presented in table 1 . Whereas in table 2 the measurement results of the tractor model motion parameters at the increased movement resistance were presented in table 2 (movement on the grass $\mu=0.8$ ). The results were obtained after the use of popular relations and were presented with a precision to 0.01 .

Table 3 presents the results of the maximum distance which may be made by a tractor model for the set loads and temperatures of the surrounding.

Based on the obtained test results presented in table 1 and 2 diagrams of relation of power and energy collected from batteries and time of drive on the measurement length of $100 \mathrm{~m}$ for the tests performed in $20^{\circ} \mathrm{C}, 10^{\circ} \mathrm{C}$ and $0^{\circ} \mathrm{C}$ were presented in figure 1 and 2 . 
Table 1.

Results of measurements of energy consumption by a tractor model during driving on dry concrete $(\mu=1)$

\begin{tabular}{|c|c|c|c|c|}
\hline \multicolumn{3}{|c|}{ Registration of values } & Average & $\begin{array}{l}\text { Standard } \\
\text { deviation }\end{array}$ \\
\hline Parameter & $\begin{array}{c}\text { Temperature } \\
\text { of the surrounding } \\
\left({ }^{\circ} \mathrm{C}\right)\end{array}$ & $\begin{array}{c}\text { Total model } \\
\text { mass } \\
(\mathrm{kg})\end{array}$ & $\bar{X}$ & $\sigma$ \\
\hline$U_{\text {zest }}(\mathrm{V})$ & \multirow{6}{*}{20} & \multirow{6}{*}{316.5} & 63.15 & 0.362859 \\
\hline$\Delta U_{\text {zest }}(\mathrm{V})$ & & & 0.34 & 0.084327 \\
\hline$I(\mathrm{~A})$ & & & 31.828 & 0.113412 \\
\hline$t(\mathrm{~s})$ & & & 93.31 & 0.179196 \\
\hline$P(\mathrm{~W})$ & & & 10.829 & 2.699212 \\
\hline$E(\mathrm{Wh})$ & & & 0.281 & 0.069354 \\
\hline$U_{\text {zest }}(\mathrm{V})$ & \multirow{6}{*}{20} & \multirow{6}{*}{396.5} & 63.47 & 0.048305 \\
\hline$\Delta U_{\text {zest }}(\mathrm{V})$ & & & 0.53 & 0.096609 \\
\hline$I(\mathrm{~A})$ & & & 35.355 & 0.269619 \\
\hline$t(\mathrm{~s})$ & & & 105.61 & 1.288798 \\
\hline$P(\mathrm{~W})$ & & & 18.743 & 1.726654 \\
\hline$E(\mathrm{Wh})$ & & & 0.551 & 0.046296 \\
\hline$\overline{U_{\text {zest }}(\mathrm{V})}$ & \multirow{6}{*}{10} & \multirow{6}{*}{316.5} & 63.25 & 0.117851 \\
\hline$\Delta U_{\text {zest }}(\mathrm{V})$ & & & 1.31 & 0.11005 \\
\hline$I(\mathrm{~A})$ & & & 31.99 & 0.1076 \\
\hline$t(\mathrm{~s})$ & & & 93.31 & 0.166333 \\
\hline$P(\mathrm{~W})$ & & & 41.912 & 3.591533 \\
\hline$E(\mathrm{Wh})$ & & & 1.086 & 0.093357 \\
\hline$\overline{U_{\text {zest }}(\mathrm{V})}$ & \multirow{6}{*}{10} & \multirow{6}{*}{396.5} & 63.22 & 0.113529 \\
\hline$\Delta U_{\text {zest }}(\mathrm{V})$ & & & 2.46 & 0.107497 \\
\hline$I(\mathrm{~A})$ & & & 36.075 & 0.218238 \\
\hline$t(\mathrm{~s})$ & & & 109.5 & 0.309121 \\
\hline$P(\mathrm{~W})$ & & & 88.757 & 3.984983 \\
\hline$E(\mathrm{Wh})$ & & & 2.701 & 0.119019 \\
\hline$U_{\text {zest }}(\mathrm{V})$ & \multirow{6}{*}{0} & \multirow{6}{*}{316.5} & 62.74 & 0.259058 \\
\hline$\Delta U_{\text {zest }}(\mathrm{V})$ & & & 4.59 & 0.11005 \\
\hline$I(\mathrm{~A})$ & & & 31.72 & 0.163639 \\
\hline$t(\mathrm{~s})$ & & & 93.65 & 0.501664 \\
\hline$P(\mathrm{~W})$ & & & 145.6 & 3.798763 \\
\hline$E(\mathrm{Wh})$ & & & 3.788 & 0.10315 \\
\hline$\overline{U_{\text {zest }}(\mathrm{V})}$ & \multirow{6}{*}{0} & \multirow{6}{*}{396.5} & 62.59 & 0.128668 \\
\hline$\Delta U_{\text {zest }}(\mathrm{V})$ & & & 5.14 & 0.05164 \\
\hline$I(\mathrm{~A})$ & & & 36.118 & 0.207996 \\
\hline$t(\mathrm{~s})$ & & & 113.3 & 0.678233 \\
\hline$P(\mathrm{~W})$ & & & 185.647 & 2.148638 \\
\hline$E(\mathrm{Wh})$ & & & 5.842 & 0.059777 \\
\hline
\end{tabular}


Analysis of energy...

Table 2.

Results of measurement of energy consumption by a tractor model during driving at the increased movement resistance - drive on grass $(\mu=0.8)$

\begin{tabular}{|c|c|c|c|c|}
\hline \multicolumn{3}{|c|}{ Registration of values } & \multirow{2}{*}{$\begin{array}{c}\text { Average } \\
\overline{\bar{X}}\end{array}$} & \multirow{2}{*}{$\begin{array}{c}\begin{array}{c}\text { Standard } \\
\text { deviation }\end{array} \\
\sigma\end{array}$} \\
\hline Parameter & $\begin{array}{l}\text { Temperature of the } \\
\text { surrounding } \\
\left({ }^{\circ} \mathrm{C}\right)\end{array}$ & $\begin{array}{c}\text { Total model mass } \\
(\mathrm{kg})\end{array}$ & & \\
\hline$\overline{U_{\text {zest }}(\mathrm{V})}$ & \multirow{6}{*}{20} & \multirow{6}{*}{316.5} & 63.31 & 0.08756 \\
\hline$\Delta U_{\text {zest }}(\mathrm{V})$ & & & 0.74 & 0.069921 \\
\hline$I(\mathrm{~A})$ & & & 33.494 & 0.343809 \\
\hline$t(\mathrm{~s})$ & & & 93.69 & 0.328126 \\
\hline$P(\mathrm{~W})$ & & & 24.782 & 2.30263 \\
\hline$E(\mathrm{Wh})$ & & & 0.646 & 0.058727 \\
\hline$\overline{U_{\text {zest }}(\mathrm{V})}$ & \multirow{6}{*}{20} & \multirow{6}{*}{396.5} & 63.33 & 0.125167 \\
\hline$\Delta U_{\text {zest }}(\mathrm{V})$ & & & 1.18 & 0.091894 \\
\hline$I(\mathrm{~A})$ & & & 37.684 & 0.421089 \\
\hline$t(\mathrm{~s})$ & & & 105.09 & 1.327864 \\
\hline$P(\mathrm{~W})$ & & & 44.483 & 3.397143 \\
\hline$E(\mathrm{Wh})$ & & & 1.297 & 0.093814 \\
\hline$U_{\text {zest }}(\mathrm{V})$ & \multirow{6}{*}{10} & \multirow{6}{*}{316.5} & 63.26 & 0.069921 \\
\hline$\Delta U_{\text {zest }}(\mathrm{V})$ & & & 1.67 & 0.11595 \\
\hline$I(\mathrm{~A})$ & & & 34.694 & 0.29774 \\
\hline$t(\mathrm{~s})$ & & & 95.63 & 1.048862 \\
\hline$P(\mathrm{~W})$ & & & 57.956 & 4.299618 \\
\hline$E(\mathrm{Wh})$ & & & 1.539 & 0.100493 \\
\hline$U_{\text {zest }}(\mathrm{V})$ & \multirow{6}{*}{10} & \multirow{6}{*}{396.5} & 63.29 & 0.073786 \\
\hline$\Delta U_{\text {zest }}(\mathrm{V})$ & & & 3.3 & 0.094281 \\
\hline$I(\mathrm{~A})$ & & & 37.943 & 0.298293 \\
\hline$t(\mathrm{~s})$ & & & 115.09 & 0.502107 \\
\hline$P(\mathrm{~W})$ & & & 125.235 & 4.490769 \\
\hline$E(\mathrm{Wh})$ & & & 4.002 & 0.12891 \\
\hline$U_{\text {zest }}(\mathrm{V})$ & \multirow{6}{*}{0} & \multirow{6}{*}{316.5} & 62.73 & 0.211082 \\
\hline$\Delta U_{\text {zest }}(\mathrm{V})$ & & & 4.57 & 0.125167 \\
\hline$I(\mathrm{~A})$ & & & 33.751 & 0.492374 \\
\hline$t(\mathrm{~s})$ & & & 100.08 & 0.798332 \\
\hline$P(\mathrm{~W})$ & & & 154.294 & 6.328885 \\
\hline$E(\mathrm{Wh})$ & & & 4.287 & 0.143531 \\
\hline$U_{\text {zest }}(\mathrm{V})$ & \multirow{6}{*}{0} & \multirow{6}{*}{396.5} & 62.48 & 0.229976 \\
\hline$\Delta U_{\text {zest }}(\mathrm{V})$ & & & 6.13 & 0.356059 \\
\hline$I(\mathrm{~A})$ & & & 38.674 & 0.474955 \\
\hline$t(\mathrm{~s})$ & & & 116.9 & 1.345775 \\
\hline$P(\mathrm{~W})$ & & & 237.11 & 16.68725 \\
\hline$E(\mathrm{Wh})$ & & & 7.695 & 0.443703 \\
\hline
\end{tabular}


Table 3.

Measurement results of the maximum distance

\begin{tabular}{|c|c|c|c|c|}
\hline Parameter & Value & $\begin{array}{c}\text { Temperature of } \\
\text { surrounding }\left({ }^{\circ} \mathrm{C}\right)\end{array}$ & $\begin{array}{c}\text { Total model mass } \\
(\mathrm{kg})\end{array}$ & $\begin{array}{c}\text { Distance } \\
(\mathrm{m})\end{array}$ \\
\hline$\overline{U_{\text {zest }}(\mathrm{V})}$ & 63.5 & \multirow{6}{*}{20} & \multirow{6}{*}{316.5} & \multirow{6}{*}{2530} \\
\hline$\Delta U_{\text {zest }}(\mathrm{V})$ & 18.5 & & & \\
\hline$I(\mathrm{~A})$ & 32 & & & \\
\hline$t(\mathrm{~s})$ & 2363 & & & \\
\hline$P(\mathrm{~W})$ & 592 & & & \\
\hline$E(\mathrm{Wh})$ & 388.58 & & & \\
\hline$U_{\text {zest }}(\mathrm{V})$ & 63.5 & \multirow{6}{*}{20} & \multirow{6}{*}{396.5} & \multirow{6}{*}{2172} \\
\hline$\Delta U_{\text {zest }}(\mathrm{V})$ & 18.5 & & & \\
\hline$I(\mathrm{~A})$ & 34 & & & \\
\hline$t(\mathrm{~s})$ & 2412 & & & \\
\hline$P(\mathrm{~W})$ & 629 & & & \\
\hline$E(\mathrm{Wh})$ & 421.43 & & & \\
\hline$U_{\text {zest }}(\mathrm{V})$ & 63.4 & \multirow{6}{*}{10} & \multirow{6}{*}{316.5} & \multirow{6}{*}{2181} \\
\hline$\Delta U_{\text {zest }}(\mathrm{V})$ & 18.4 & & & \\
\hline$I(\mathrm{~A})$ & 32 & & & \\
\hline$t(\mathrm{~s})$ & 2378 & & & \\
\hline$P(\mathrm{~W})$ & 588.8 & & & \\
\hline$E(\mathrm{Wh})$ & 388.93 & & & \\
\hline$\overline{U_{\text {zest }}(\mathrm{V})}$ & 63.5 & \multirow{6}{*}{10} & \multirow{6}{*}{396.5} & \multirow{6}{*}{1692} \\
\hline$\Delta U_{\text {zest }}(\mathrm{V})$ & 18.5 & & & \\
\hline$I(\mathrm{~A})$ & 35 & & & \\
\hline$t(\mathrm{~s})$ & 2467 & & & \\
\hline$P(\mathrm{~W})$ & 647.5 & & & \\
\hline$E(\mathrm{Wh})$ & 443.72 & & & \\
\hline$\overline{U_{\text {zest }}(\mathrm{V})}$ & 62.8 & \multirow{6}{*}{0} & \multirow{6}{*}{316.5} & \multirow{6}{*}{1822} \\
\hline$\Delta U_{\text {zest }}(\mathrm{V})$ & 17.8 & & & \\
\hline$I(\mathrm{~A})$ & 33 & & & \\
\hline$t(\mathrm{~s})$ & 2406 & & & \\
\hline$P(\mathrm{~W})$ & 587.4 & & & \\
\hline$E(\mathrm{Wh})$ & 392.58 & & & \\
\hline$U_{\text {zest }}(\mathrm{V})$ & 62.8 & \multirow{6}{*}{0} & \multirow{6}{*}{396.5} & \multirow{6}{*}{1178} \\
\hline$\Delta U_{\text {zest }}(\mathrm{V})$ & 17.8 & & & \\
\hline$I(\mathrm{~A})$ & 36 & & & \\
\hline$t(\mathrm{~s})$ & 2532 & & & \\
\hline$P(\mathrm{~W})$ & 640.8 & & & \\
\hline$E(\mathbf{W h})$ & 450.70 & & & \\
\hline
\end{tabular}

Based on the obtained test results presented in table 3, diagrams of relation of power and energy collected from batteries, maximum distance, and drive time for tests performed in $20^{\circ} \mathrm{C}, 10^{\circ} \mathrm{C}$ and $0^{\circ} \mathrm{C}$ for the total weight of the tractor $316.5 \mathrm{~kg}$ and $396.5 \mathrm{~kg}$ which were presented in figure 3 and 4 , were made. 
Analysis of energy...
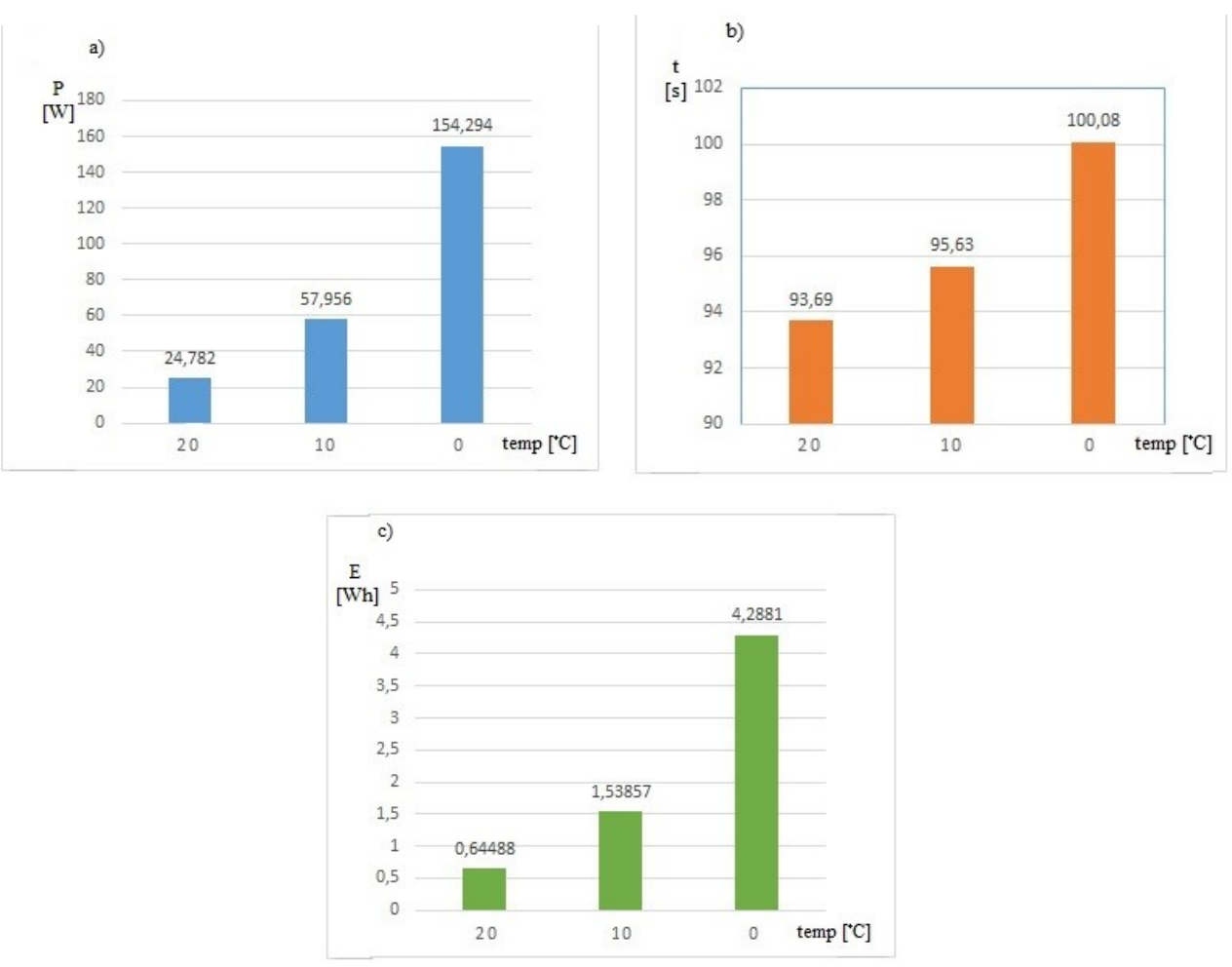

Figure 1. Relations of power and energy collected from the set of batteries, and time of drive in relation to the temperature of the surrounding for the tractor model mass $316.5 \mathrm{~kg}$, a) power $P(W), b)$ drive time $t(s), c)$ energy $E(W h)$ 

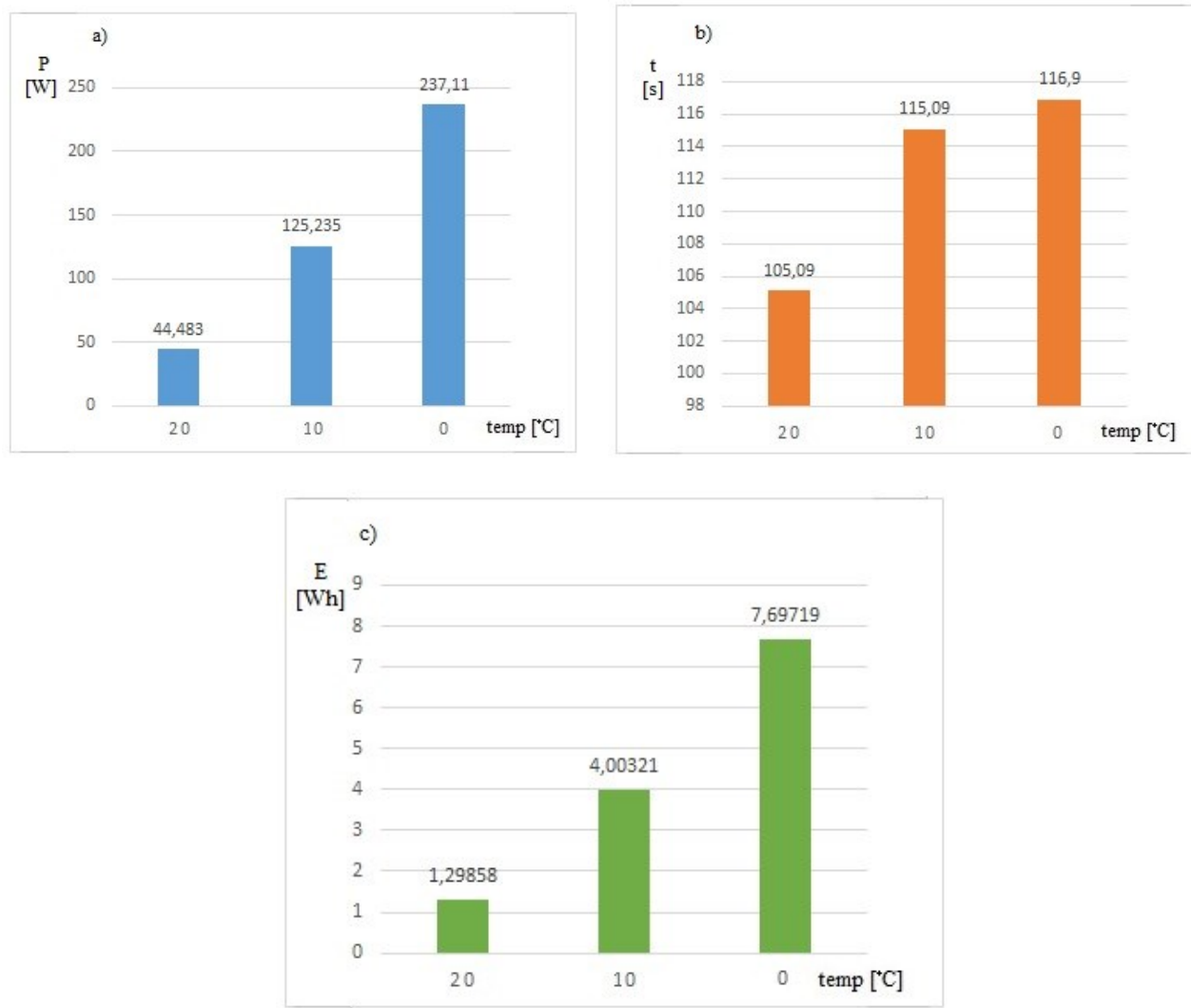

Figure 2. Relations of power and energy collected from the set of batteries and time of drive in relation to the temperature of the surrounding for the tractor model mass $396.5 \mathrm{~kg}$, a) power $P(W), b)$ drive time $t(s), c)$ energy $E(W h)$ 
Analysis of energy...

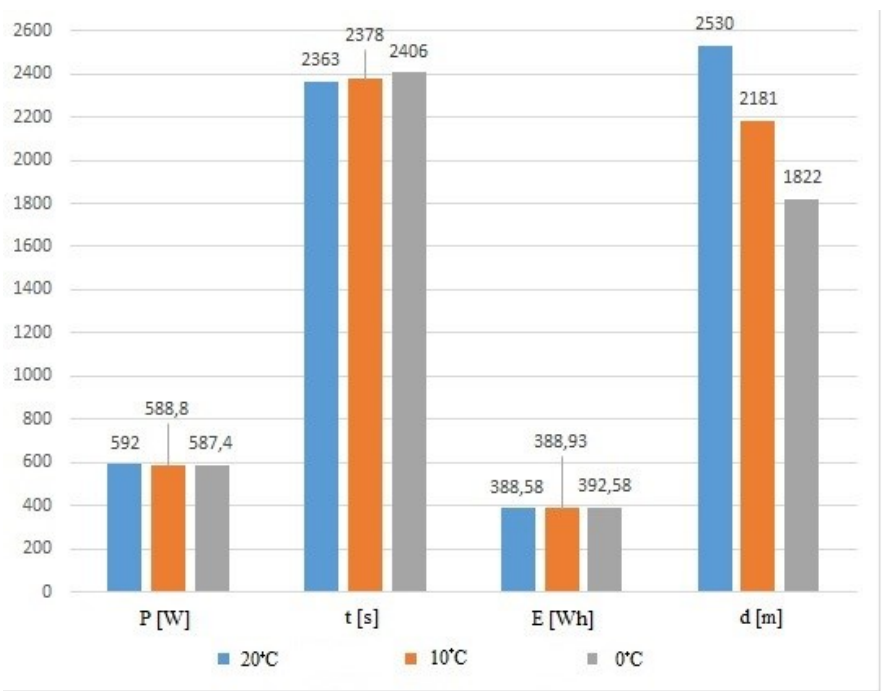

Figure 3. Relations of power and energy collected from the set of batteries, drive time and distance in relation to the temperature of the surrounding for the tractor model mass of $316.5 \mathrm{~kg}$

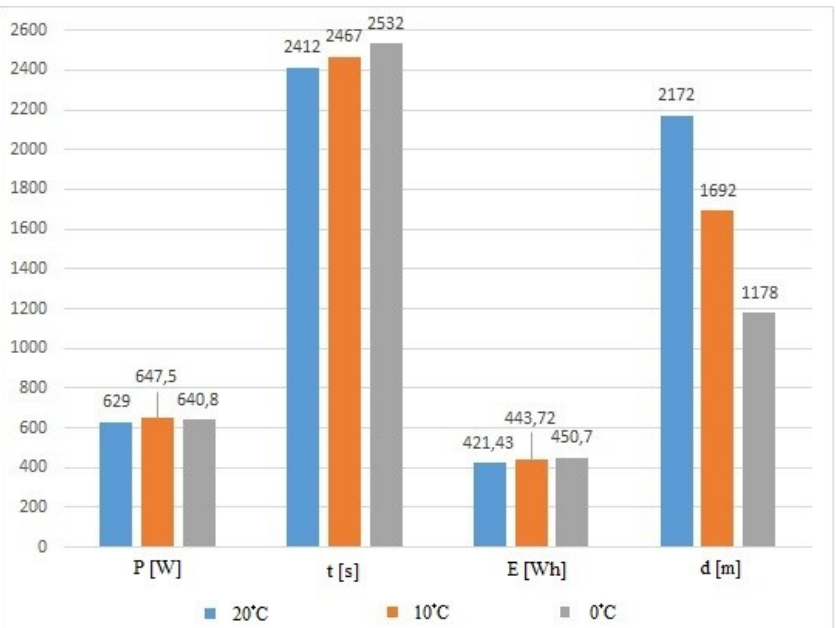

Figure 4. Relations of power and energy collected from the set of batteries, drive time and distance in relation to the temperature of the surrounding for the tractor model mass of $396.5 \mathrm{~kg}$ 
During the drive of the measured distance of $100 \mathrm{~m}$ with a small increase of the drive time and along with the temperature reduction, the amount of the collected power $P$ and energy $E$ raises for both used total masses of the tractor with the power transmission system. It is particularly visible for the relation of the collected power for both loads of the power transmission system within the range of temperature $0^{\circ} \mathrm{C}$. The increase of the power value collected from the set of batteries was respectively $133 \%$ for $10 \%$ in comparison to the value of power collected at $20^{\circ} \mathrm{C}$ and the following $166 \%$ for the temperature of $0^{\circ} \mathrm{C}$ for the total mass of the tractor set of $316.5 \mathrm{~kg}$ and $181.5 \%$ and $89.3 \%$ for the mass of the set of $396.5 \mathrm{~kg}$ (fig. 2a). The reported increase of the consumed energy was respectively $138.5 \%$ for $10^{\circ} \mathrm{C}$ in comparison to the energy collected at $20^{\circ} \mathrm{C}$ and $178.7 \%$ for $0^{\circ} \mathrm{C}$ in comparison to the energy collected at $10^{\circ} \mathrm{C}$ for the total mass of the set of $316.5 \mathrm{~kg}$ and for $396.5 \mathrm{~kg}$ of the mass the increase of the value of the collected energy was respectively $208 \%$ for $10^{\circ} \mathrm{C}$ and another $92 \%$ for $0^{\circ} \mathrm{C}$

The diagrams of power consumption $P$ and energy $E$ for the applied masses of a tractor in relation to the temperature of the surrounding presented in figure 3 and 4 show that similar values were obtained regardless the external conditions. However, in this case, the drive time slightly increased at a simultaneous reduction of the maximum range of drive. During the studies, values of the driven distance of $2530 \mathrm{~m}$ at $20^{\circ} \mathrm{C}$ which was reduced to $1822 \mathrm{~m}$ at $0^{\circ} \mathrm{C}$ for the tractor set mass of $316.5 \mathrm{~kg}$ were obtained, whereas for the mass of the set of $396.6 \mathrm{~kg}$ it was respectively $3172 \mathrm{~m}$ at $20^{\circ} \mathrm{C}$ and $1178 \mathrm{~m}$ at $0^{\circ} \mathrm{C}$. Reasons for this state of affairs should be searched for in the condition of the batteries used for studies (used).

In the available literature (Chłopek, 2013; Torbus et al., 2017) the tests on the electric energy consumption during the road tests for an electric passenger car may be found. In the paper (Torbus et al., 2017) tests on the impact of temperature on the parameters of operation of the electric traction engine supplied from Li-Ion batteries, were performed. However, the available references do not contain operation tests of an electric power transmission system of a farm tractor.

\section{Conclusion}

Due to the increasing number of vehicles and constant development of transport and thereby a constantly increasing pollution of the natural environment with exhaust gases possibilities of replacing combustion drive vehicles with another type of a drive e.g., an electric one, are searched for.

An electric drive used in the tractor model enabled performance of a basic analysis of energy consumption during the drive on the hardened surface and on the non-hardened area. The presented research results of show considerable differences in energy consumption, time of tractor operation (a drive range) in relation to the temperature of the surrounding and load of the power transmission system. Quite puzzling is the obtained growth of consumption of the collected power $P$ and energy $E$ from the supplying set for the temperatures of the surrounding of $10^{\circ} \mathrm{C}$ and $0^{\circ} \mathrm{C}$ in comparison to these values obtained at the temperature of $20^{\circ} \mathrm{C}$. For the set measurement length of $100 \mathrm{~m}$ the obtained results of research show the increase of energy consumption even by $181 \%$ of the collected active power from the set of batteries and the drive time for both used total masses of the tractor model and the selected temperature of the surrounding. However, remarkably high differences of the maximum range of drive 
for the applied loads in relation to the temperature of the surrounding at quite slight changes of the remaining parameters are interesting.

\section{References}

Andersen, O. (2013). Towards the Use of Electric Cars. In: Unintended Consequences of Renewable Energy. Green Energy and Technology. Springer, London. https://doi.org/10.1007/978-1-44715532-4_6.

Bakun, B. (2015). Zagadnienie jednostkowego zużycia energii pojazdu elektrycznego na przykładzie samochodu osobowego po konwersji napędu. Przegląd Elektrotechniczny, 2, 174-176.

Chłopek, Z. (2013). Ocena drogowego zużycia energii przez samochód elektryczny. Transport Samochodowy, 2, 75-87.

Daberkow, A., Ehlert, M., Kaise, D. (2013). Electric Car Operation and Flywheel Energy Storage. In: Lienkamp M. (eds) Conference on Future Automotive Technology. Springer Vieweg, Wiesbaden. https://doi.org/10.1007/978-3-658-01141-3_2.

Eckl, R., Burda, P., Foerg, A., Finke, H., Lienkamp, M. (2013). Alternative Range Extender for Electric Cars - Zinc Air Batteries. In: Lienkamp M. (eds) Conference on Future Automotive Technology. Springer Vieweg, Wiesbaden. https://doi.org/10.1007/978-3-658-01141-3_1.

Engstle, A., Deiml, M., Schlecker, M., Angermaier, A. (2012). Development of an 800-V Electric Car with Rear-Wheel Drive. ATZ worldwide, 114, 7-44.

Haidar, A., Razali, R., Abdalla, A., Aziz, H.A., Noman, K., Al-Jawfi, R. (2011). Protection of Solar Electric Car DC Motor with PIC Controller. In: Zhu M. (eds) Electrical Engineering and Control. Lecture Notes in Electrical Engineering. Vol 98. Springer, Berlin, Heidelberg. https://doi.org /10.1007/978-3-642-21765-4_19.

Hüpkes, S., Hillebrand, G., Brings, W. (2011). Flexible powertrain for electric cars. ATZ worldwide eMagazine, 113, 12-19. https://doi.org/10.1365/s38311-011-0120-6.

Król, E., Rossa, R. (2017). Samochód osobowy z napędem elektrycznym- zimowe testy eksploatacyjne. Maszyny Elektryczne - Zeszyty Problemowe, 2(114), 251-256.

Marcus, A.A., Fremeth, A.R. (2009). Green Management Matters Regardless. Academy of Management Perspectives, 23, 17-26. https://doi.org/10.5465/amp.2009.43479261.

Michałowski, K. Ocioszyński, J. (1989). Pojazdy samochodowe o napędzie elektrycznym i hybrydowym. WKŁ, Warszawa. ISBN 8320607612.

Moons, I., De Pelsmacker, P. (2014). Developing Different Types of Anticipated Experience Positioning for Electric Cars. Journal of Brand Management, 21, 216-235. https://doi.org/10.1057/bm. 2014.2.

Schneider, J., Stamm, K., Breitenbach, F. (2011). Production Concept for an Electric Car. ATZproduktion worldwide eMagazine, 4(2), 4-9. https://doi.org/10.1365/s38312-011-0010-3.

Torbus, B., Meinicke, T., Tyrtania, R. (2017). Ocena wpływu temperatury na zasięg, obciążalność i możliwość rozruchu pojazdu elektrycznego zasilanego z baterii trakcyjnej typu Li-Ion. Maszyny Elektryczne - Zeszyty Problemowe. 1(113), 43-47. 


\title{
ANALIZA ZUŻYCIA ENERGII PRZEZ MODEL ELEKTRYCZNEGO CIĄGNIKA ROLNICZEGO W WARUNKACH EKSPLOATACYJNYCH
}

\begin{abstract}
Streszczenie. Celem pracy jest analiza zużycia energii elektrycznej niezbędnej do napędu ciągnika rolniczego $\mathrm{z}$ silnikiem elektrycznym jako jednostką napędową, w warunkach jazdy $\mathrm{z}$ różnym obciążeniem układu napędowego. Obiektem badań był model ciągnika, w którym silnik spalinowy został zastąpiony silnikiem elektrycznym prądu stałego. W trakcie prób rejestrowano spadek napięcia oraz natężenie prądu pobieranego $\mathrm{z}$ baterii akumulatorów zasilających $\mathrm{w}$ funkcji czasu jazdy ciągnika, a także w zależności od masy ciągnika z przyczepą, temperatury otoczenia oraz oporów ruchu, co pozwoliło na określenie pobranej mocy i energii. Dla zastosowanego zestawu akumulatorów określono również maksymalny zasięg jazdy ciągnika po drodze utwardzonej.
\end{abstract}

Słowa kluczowe: ciągnik rolniczy, silnik elektryczny, układ napędowy, zużycie energii 